\title{
A COMPARATIVE STUDY OF MULTINATIONAL SUBSIDIARIES AND LOCAL COMPANIES IN EMERGING ECONOMIES: A MANUFACTURING PRACTICE APPROACH*
}

\author{
Levente SZÁSZ - Béla Gergely RÁCZ - Anca BORZA - Botond BENEDEK
}

(Received: 28 May 2019; revision received: 20 October 2019;

accepted: 28 October 2019)

\begin{abstract}
This paper investigates whether multinational companies possess superior manufacturing knowledge relative to domestic companies operating in emerging market countries. Manufacturing knowledge is operationalized as knowledge in use through the implementation and performance impact of manufacturing practices. Using survey data of 216 manufacturing plants located in five emerging countries, we apply analysis of variance (ANOVA) and structural equation modelling (SEM) to identify the potential knowledge surplus of multinational subsidiaries over local companies. Results of our analysis show that, generally, multinational subsidiaries invest significantly more effort in implementing manufacturing practices. Nevertheless, their knowledge superiority concerning the effective use of these practices is only materialized in terms of practices related to human resource development and advanced manufacturing technologies.
\end{abstract}

Keywords: multinational companies, best practice, knowledge management, knowledge transfer, emerging markets

JEL classification indices: F23, M11, O14

* The research was funded by UEFISCDI Romania (Executive Agency for Higher Education, Research, Development and Innovation Funding), project No. PN-III-P1-1.1-TE-2016-0502.

Levente Szász, corresponding author. Vice Dean and Full Professor at the Faculty of Economics and Business Administration, Babeş-Bolyai University, Cluj-Napoca, Romania. E-mail: levente. szasz@econ.ubbcluj.ro

Béla Gergely Rácz, Assistant Professor at the Faculty of Economics and Business Administration, Babeş-Bolyai University, Cluj-Napoca, Romania. E-mail: bela.racz@econ.ubbcluj.ro

Anca Borza, Full Professor at the Faculty of Economics and Business Administration, BabeşBolyai University, Cluj-Napoca, Romania. E-mail: anca.borza@econ.ubbcluj.ro

Botond Benedek, Teaching Assistant at the Faculty of Economics and Business Administration, Babeş-Bolyai University, Cluj-Napoca, Romania. E-mail: botond.benedek@econ.ubbcluj.ro 


\section{INTRODUCTION}

This paper focuses on manufacturing plants operating in the emerging economies, including both domestic manufacturing plants and plants belonging to multinational companies (MNCs), and investigates whether MNC subsidiaries located in these countries possess superior manufacturing knowledge relative to local manufacturing plants. The starting point of this endeavor is that nowadays the majority of manufacturing MNCs recognize that, by operating international networks of manufacturing subsidiaries dispersed in different countries, including both developed and emerging countries (London - Hart 2004; Cheng et al. 2011), they can improve their competitiveness in the global market. The main source of this competitive advantage is that different subsidiaries possess different knowledge and develop different capabilities that can be combined and used throughout the internal network of an MNC (Kogut - Zander 1993; Gupta - Govindarajan 2000; Van Wijk et al. 2008). For MNC subsidiaries located in the emerging countries, this intra-company knowledge diversity implies that they can access valuable knowledge residing within their network and transfer it to increase their own manufacturing capabilities, and through this strengthen their positions within the network (Tsai 2001; Anh et al. 2006). This possibility is, however, not given for domestic manufacturing plants that have fewer linkages, and therefore, fewer opportunities to enhance their knowledge base.

Contrary to the knowledge sharing argument, several authors point out that manufacturing MNCs continue to locate subsidiaries in the emerging countries mainly due to the low cost advantages (Dachs et al. 2006; Szász - Demeter 2015). These plants contribute only with low value-added, repetitive manufacturing tasks to the competitiveness of the whole network (Mudambi 2008; Hansen et al. 2009; Jensen - Pedersen 2011), and do not fully use the knowledge potential residing within the intra-company network. Thus, the advantage of these subsidiaries over domestic companies in terms of manufacturing knowledge is still questionable.

The debate whether MNC subsidiaries located in emerging countries truly possess superior manufacturing knowledge relative to domestic companies is also implicitly touched by the knowledge spillover literature. Authors belonging to this stream imply that MNCs possess superior manufacturing and technological knowledge (Marin - Bell 2006). This knowledge can be shared by the MNC subsidiary located in an emerging country with domestic suppliers, customers, competing firms and local institutions (Sveiby 2001; Javorcik 2004; Wei - Liu 2006; Hansen et al. 2009; Firth - Gauri 2010). This process is facilitated by the phenomenon referred to as the "dual embeddedness" of subsidiaries (Figueiredo 2011; Meyer et al. 2011), whereby MNC subsidiaries create knowledge-intensive linkages with members of both the internal (other MNC units) and external (sup- 
ply chain partners, competitors, local institutions) network (Achcaoucaou et al. 2014; Mariotti et al. 2015; Golini et al. 2016; Bresciani - Ferraris 2016; Demeter et al. 2016; Ferraris et al. 2017). Although the existence and positive impact of such knowledge spillovers is backed up by several studies, evidence is still not conclusive (Javorcik 2004; Mariotti et al. 2015).

However, it is not the purpose of this paper to bring further evidence for the knowledge spillover effect in the emerging countries. More specifically, we rather aim to open up the black box of manufacturing plants and investigate on the level of manufacturing practices; whether MNC subsidiaries located in the emerging countries have superior knowledge compared to the domestic manufacturing firms. This possible knowledge advantage would create the potential for knowledge spillovers in the host economy, as it represents the knowledge of MNC subsidiaries that is new or unknown to domestic firms.

By opening up the black box of these manufacturing units, we also aim to fill an important gap in the literature, as previous studies offer little guidance on what the exact manufacturing knowledge domains are in which the MNC subsidiaries have an actual advantage over the local manufacturing firms. Spillover studies generally investigate whether and under what circumstances the knowledge transfer takes place and how it contributes to the performance of companies in the host country (e.g. Caves 1974; Blomström - Kokko 1998; Javorcik 2004; Wei - Liu 2006; Mariotti et al. 2015), but none of them opens up the black box of these companies to investigate the specific manufacturing knowledge areas in which the MNC subsidiaries have an advantage over the domestic firms. Beside spillover studies, there are several papers that investigate the advantage of MNCs over domestic companies, for example in terms of investments in research and development (Bae - Noh 2001), strategy (Lavie - Fiegenbaum 2003) or financial performance (Michel Shaked 1986; Barbosa - Louri 2005; Greene et al. 2009), but none of these papers focuses on the core function of manufacturing firms, or more precisely on the knowledge embedded in the manufacturing practices of these companies. Thus, in order to fill this gap in the literature, our study aims to answer the following research question: Do MNC subsidiaries located in emerging countries possess superior manufacturing knowledge compared to domestic companies?

In this paper, we operationalize manufacturing knowledge through manufacturing practices, following several authors who argue that practices represent the manifestation of knowledge in use (Szulanszki 1996; O’Dell - Grayson 1998; Kostova 1999; Ferdows 2006). These practices, once implemented, are meant to improve the performance of manufacturing firms (Laugen et al. 2005; Demeter et al. 2017).

The paper is organized as follows. In Section 2 we provide a description of the background literature, adopting a framework in the first step that conceptualizes 
the role of MNCs in the emerging economies. Besides this, we review recent empirical findings on the different roles of MNC subsidiaries located in the emerging countries, highlighting the contrasting views on the manufacturing knowledge of MNC subsidiaries compared to that of the domestic manufacturing firms. Lastly, we provide a summary of previous studies on manufacturing practices that aids us in operationalizing the manufacturing knowledge of the organizations involved in our study. Section 3 presents the survey method and research design employed in this paper. Section 4 describes the results of the analyses, while in Section 5 we discuss the findings and draw the conclusions of the study.

\section{LITERATURE REVIEW}

\subsection{Conceptualizing the role of MNCs in the emerging countries}

MNCs are viewed as a network of headquarter(s) and subsidiaries spread across vast geographical locations in which firm-specific advantages can be combined with local advantages to ensure the competitiveness of the MNCs in the global market (Dunning 1998). Subsidiaries within this network do not operate in isolation. Instead, they develop connections with both company-internal units (e.g. Kogut - Zander 1993; Minbaeva 2007; Szász et al. 2016) and external actors (e.g. Andersson et al. 2002, 2005; Easterby-Smith et al. 2008; Kawai 2012), where knowledge can be transferred in any possible direction (Gupta - Govindarajan 2000; Van Wijk et al. 2008; Yang et al. 2008), i.e. knowledge inflows and outflows between an MNC subsidiary and an internal or external partner.

Meyer et al. (2011) offer a useful theoretical framework to conceptualize the complex interactions between MNC subsidiaries and local contexts. The central tenet of this framework is that MNC knowledge is not only shaped by knowledge creation in the home base (headquarter), but also by knowledge generated within subsidiaries that interacts with their specific host contexts (Almeida - Phene 2004; Meyer et al. 2011). In this paper we adapt this framework to understand the role of MNCs in the emerging economies (Figure 1).

The framework can be used to highlight the role of emerging country MNC subsidiaries (i.e. the lower left part of the framework) from three different, but complementary perspectives, namely the perspective of the subsidiary, the MNC and the local economy.

First, from the perspective of the subsidiaries located in the emerging countries, these units need to develop links to other intra-organizational units to be able to access knowledge residing within the network (Tsai 2001; Szász et al. 2016); simultaneously they also need to enhance their capacity to absorb this 


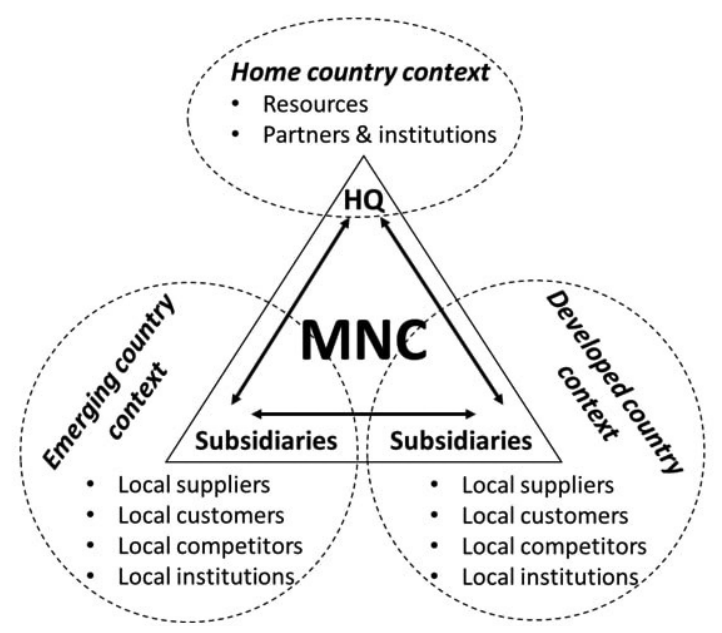

Figure 1. The interaction between MNC units and local contexts

knowledge and transform it to subsidiary-level performance (Cohen - Levinthal 1990; Tsai 2001; Lane et al. 2006). Transferred and absorbed knowledge can help subsidiaries to increase their capabilities and performance, which in turn will strengthen the position of the subsidiary within the network of the MNC (Ferdows 1997; Feldmann - Olhager 2013; Mudambi et al. 2014). Strong network position implies that the subsidiary has a substantial contribution to the capabilities of the whole network, thereby securing its existence within the MNC, i.e. avoiding potential relocation or plant closure (Birkinshaw 1996; Fusco - Spring 2003). In short, it is in the own interest of the MNC subsidiaries located in the emerging countries to transfer valuable knowledge from other units within the intra-company network.

Second, from an MNC perspective, the emerging country subsidiaries bring important low-cost benefits to the company (Dachs et al. 2006; Szász - Demeter 2015). Being located in a context where resources are less costly, subsidiary operations can be carried out with higher resource efficiency. These operations, however, generally involve low value-added manufacturing activities (Mudambi 2008; Hansen et al. 2009; Jensen - Pedersen 2011; Ambroziak 2018) that might not be central to the competitiveness of the MNC. This implies that MNCs might not be motivated to transfer their most valuable manufacturing knowledge to the emerging country subsidiaries. On the other hand, the emerging country subsidiaries with increased manufacturing knowledge represent more value to the entire network, and such a knowledge transfer might still be beneficial to the competitiveness of the whole MNC (Birkinshaw et al. 1998; Frost et al. 2002; Fusco 
- Spring 2003). Furthermore, the general argument to geographically co-locate manufacturing and R\&D activities (Ketokivi - Ali-Yrkkö, 2009) represents another driver for the emerging country subsidiaries to transfer valuable technological knowledge from other MNC units (Kinoshita 2001; Damijan et al. 2003).

Third, from the viewpoint of the emerging country in which the subsidiary is located, potential benefits are clearly identified in the literature. By sharing internal knowledge with local partners (Blomström - Kokko 1998; Wei - Liu 2006; Mariotti et al. 2015), MNC subsidiaries located in the emerging countries can contribute to the development of competences of domestic firms that cooperate with the focal subsidiary (Sveiby 2001; Mudambi 2008; Hansen et al. 2009; Firth - Gauri 2010). This contribution, however, can only take place if MNC subsidiaries located in the emerging countries possess superior manufacturing knowledge compared to the knowledge of domestic firms. This issue, however, has not yet been explored in the literature. Creating knowledge-intensive linkages with local partners (suppliers, customers, institutions, etc.) might not only contribute to the development of the local economy, but could also be beneficial for the subsidiary: internal knowledge can be recombined with the knowledge of local partners which can further increase the competences of the subsidiary and of the MNC as a whole (Andersson et al. 2002, 2005; Kawai 2012; Demeter et al. 2016; Ferraris et al. 2017).

In summary, the framework based on the Meyer et al. (2011) model explains both the low-cost motive of subsidiary operation in the emerging economies (which implies the transfer of less valuable knowledge) and, at the same time, the knowledge absorption motive of these units that can contribute to the development of the local economy as well (implying the transfer of superior manufacturing knowledge). Thus, there is no conclusive evidence on whether MNC subsidiaries located in the emerging countries truly possess superior manufacturing knowledge relative to domestic firms. Therefore, the next section reviews recent empirical findings on the two contrasting roles of subsidiaries located in the emerging countries which offer basis for the central research question of this paper.

\subsection{Empirical findings on the role of MNC subsidiaries in located the emerging countries}

Both roles of the emerging country MNC plants (i.e. performing low value-added activities, but at the same time improving capabilities via knowledge transfer) are present in recent empirical papers. For example, focusing on the offshoring activities of 207 Danish firms, Jensen - Pedersen (2011) found that, in general, the emerging countries of Central and Eastern Europe attracted less-advanced 
manufacturing activities compared to Western Europe, while R\&D processes were more frequently offshored to the developed regions. Nevertheless, the same authors found that Asia also attracted many advanced activities. Rugman et al. (2011) provided two examples in which globally leading MNCs (SGS-Thomson and Levi Strauss \& Co.) offshored their production activities - and sustained the operations of these subsidiaries - in the emerging countries (i.e. in Asia, Eastern Europe and South Africa) solely for low-cost purposes. In a survey study of 1484 German manufacturing companies, Kinkel (2012) found that low labor cost was still the most dominant off-shoring motive, the main target regions being represented by the emerging countries of Eastern Europe, China and other Asian economies. Focusing on Central and Eastern Europe (CEE), Szász - Demeter (2015) also found that low cost was the primary factor of location, but in a subsequent study of 291 manufacturing plants from 14 European countries, the same authors argued that in the CEE region a new cluster of manufacturing subsidiaries was emerging where, beside low cost, access to local knowledge and skills were also important, and accordingly these plants performed some more advanced activities (Demeter - Szász 2016). This latter category of the emerging country plants was also more involved in knowledge sharing activities with the other parts of the internal network of the MNC.

In line with this latter observation, other papers also found that MNC subsidiaries located in emerging countries did not only exploit low-cost resources, but were also intensively using the intra-network knowledge of the MNC to upgrade their capabilities. For example, Yang et al. (2008) showed that 105 subsidiaries included in their sample from Poland, Hungary and Lithuania were engaged in a considerable amount of knowledge transfer from their headquarters, and were also involved in reverse knowledge flows (i.e. from subsidiary to headquarter). Similarly, in a case-based research, Cheng et al. (2011) provided examples of how MNC subsidiaries located in 3 emerging countries (China, Estonia and Hungary) were able to upgrade their competences by using the knowledge residing within the network of the MNC. Similar upgrading process was reported by Sass - Szalavetz (2013) among the Hungarian foreign-owned subsidiaries of MNCs operating in the automotive and electronics sectors. Linares-Navarro et al. (2014) pointed out that this knowledge accumulation and upgrading was also facilitated by the fact that "the knowledge, flexibility and skills of local labor increased in many emerging countries without a corresponding increase in costs for that resource" (p.114.). Accordingly, off-shoring to the emerging countries includes more and more advanced, knowledge-intensive activities as well (ibid.). In line with this argument, Demeter - Szász (2016) found that a group of MNC subsidiaries located in the emerging countries engaged intensively in knowledge sharing to transfer new knowledge and upgrade their competences. A more recent study 
by Szász et al. (2019) shows that all emerging country case study plants in their sample engage actually in some knowledge receiving activities, some of them accumulating such amounts of manufacturing knowledge that they can also take up knowledge sending roles.

Thus, there is an ongoing debate, both in academia and in practice, about the extent to which MNC subsidiaries located in the emerging countries perform only low value-added activities with less advanced knowledge content, or they also "import" highly valuable manufacturing knowledge from their intra-company network. Moreover, to the best of our knowledge, there is no paper in the literature that would compare this knowledge content with the manufacturing knowledge of domestic companies, although such comparison would be useful in determining the knowledge spillover potential from MNC subsidiaries to manufacturing companies of the host economy. Additionally, none of the spillover studies goes beyond the general knowledge transfer to investigate on the level of different knowledge areas whether and how this spillover takes place. Although our study does not explicitly focus on spillovers, we aim to compare several manufacturing knowledge areas of MNC subsidiaries and domestic firms in the emerging countries to assess the exact areas in which the MNC subsidiaries possess superior manufacturing knowledge over the domestic firms, which would ultimately create the potential for manufacturing knowledge spillover.

\subsection{Manufacturing knowledge operationalization - the best practice approach}

As our paper specifically focuses on manufacturing firms, we take into consideration the most relevant knowledge for these types of organizations, i.e. knowledge related to the manufacturing function. Such knowledge, after being absorbed, takes up the form of manufacturing practices (Ferdows 2006). Hence, this paper operationalizes knowledge as knowledge in use, i.e. as manufacturing practices. This approach is rooted in the understanding of firms as superior knowledge transfer orchestrators, where organizational knowledge can be shared between individuals and units more efficiently within the firm than on the market (Kogut - Zander 1992). In concordance with this view, several seminal papers looked at practices as "the organization's routine use of knowledge" (Szulanski 1996: 28) or as "particular ways of conducting organizational functions $[. .$.$] that reflect the$ shared knowledge and competence of an organization" (Kostova 1999: 309).

Thus, we operationalize manufacturing knowledge through these practices, and also investigate whether these practices are "best" reflecting whether the firms possess the appropriate know-how to use these practices for improving performance (Ferdows 2006). Accordingly, the "best" manufacturing practices were 
defined as production activities and action programs that significantly contribute to the performance improvement of the manufacturing unit (Voss 1995; Laugen et al. 2005). O'Dell - Grayson (1998) considered best practices as "any practice, knowledge and know-how that had proven to be valuable or effective within an organization that may have applicability to another". Thus, while practices can be considered as the manifestation of knowledge, best practices represent "performant knowledge" (Perrin et al. 2007). The literature argues that such best practices are composed of multiple interrelated activities, rather than individual action programs (e.g. Mills et al. 1995; Shah - Ward 2003; Laugen et al. 2005; Voss 2005; Demeter et al. 2017). As a consequence, in this paper we define best practices as bundles of different action programs which are implemented in a joint manner and are supposed to positively contribute to the performance of the subsidiary.

Best practices used by manufacturing companies were widely studied in the operations management literature (Voss 1995, 2005), receiving considerable attention from scientific research since the early 1980's with the emergence and success of Japanese manufacturing management practices (Demeter et al. 2017). Authors considered several types of practices, investigating their "goodness", i.e. whether they can significantly improve the performance of manufacturing organizations (Davies - Kochhar 2002). Some authors focused on a single area of manufacturing practices, such as lean management (Shah - Ward 2003; Demeter - Matyusz 2011), quality management (Sousa - Voss 2001; Sila 2007) or integration practices (Demeter et al. 2016; Golini et al. 2016). Other authors offered a more comprehensive assessment of manufacturing best practices (e.g. Laugen et al. 2005; Da Silveira - Sousa 2010; Demeter et al. 2017), including not just practices strictly related to the manufacturing function of the firm, but also practices related to supply chain management or R\&D. ${ }^{1}$

In this paper we strictly focus on the most important practices related to the core manufacturing function of the firm, namely quality management, advanced manufacturing technology, lean process improvement and human resource management of the manufacturing function. In concordance with the main research question of this paper, the empirical part investigates whether there is a difference in the performance impact of these manufacturing practices at MNC subsidiaries and domestic firms located in the emerging countries, inferring that a significantly higher performance impact signals a better knowledge regarding the use of the certain manufacturing practices.

For a comprehensive review of best practices in manufacturing firms see Sousa - Voss (2008) and Demeter et al. (2017). 


\section{RESEARCH METHODOLOGY}

\subsection{Research sample}

To answer the research question, we used the database of the International Manufacturing Strategy Survey (IMSS). The IMSS is an international research project that was originally launched in 1992 by the London Business School and Chalmers University of Technology (www.manufacturingstrategy.net). The project focuses on manufacturing and supply chain strategies and organizational practices of companies from assembly industries (ISIC Rev. 4) by administering a detailed questionnaire simultaneously in several countries. While national research teams are responsible for the data collection in each country, a well-defined and centrally controlled data collection procedure is followed by each team. The questionnaire is targeted at production/operations managers of single plants, i.e. the person with the most comprehensive knowledge on the practices and performance of the plant. The respondents are selected from local official databases, limiting the targeted population to companies belonging to the ISIC 25-30 sectors having at least 50 employees. Potential respondents are identified and contacted via phone or e-mail before sending out the questionnaire to ask for his/her availability to participate in the survey. During the 2-3 months of national data collection follow-up calls and reminder e-mails are used to increase response rates. Completed questionnaires are collected in a central database and are thoroughly controlled for missing data, reliability and data quality. Incomplete questionnaires and unreliable answers are handled on a case-by-case basis - wherever possible - by contacting the respondents again. Questionnaires that do not meet the reliability criteria are discarded from the final database.

Since 1992 the IMSS project has been carried out six times, every 4-5 years with the participation of 600-900 companies from more than 20 countries. For our research we used the latest, sixth edition of the survey (IMSS VI), which has been carried out in 2013 and early 2014, and involved the collection of data from 931 manufacturing companies in 22 countries. We selected only the emerging countries and have collected responses both from local companies and from local subsidiaries of the developed country MNCs. Furthermore, we filtered out all respondents that had missing data on any of the variables used in this study. Finally, we used a subsample of 216 manufacturing plants from five emerging countries: two from Asia (China, Malaysia), two from Eastern Europe (Hungary, Romania), and one from South-America (Brazil). Two thirds of the sample are composed of local manufacturing plants $(\mathrm{N}=149)$, one third represents local subsidiaries of developed country MNCs $(\mathrm{N}=67)$. The process of sample selection is presented in Figure 2. 


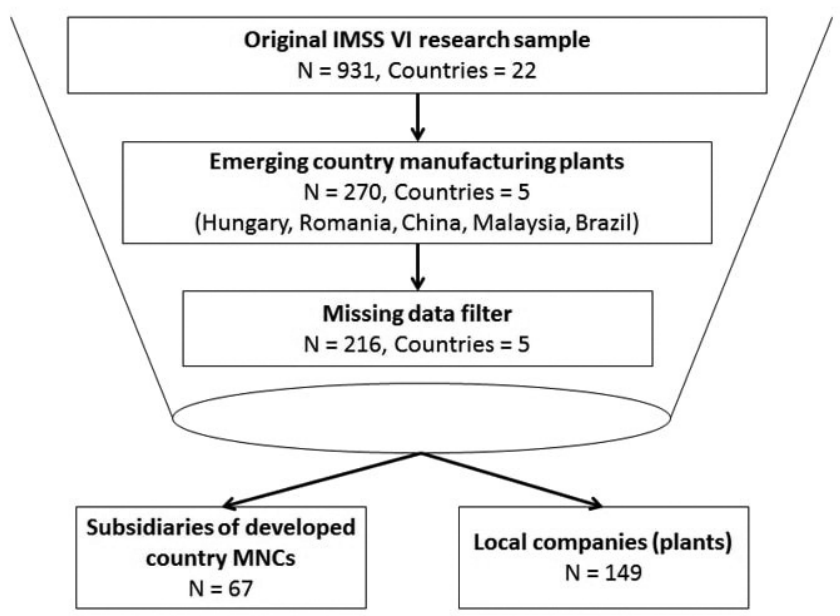

Figure 2. Research sample definition

The composition of the research sample is presented in Tables 1 and 2. Size and industry categories were defined based on previous IMSS studies (e.g. Da Silveira - Sousa 2010) to ensure the comparability and replicability of our research.

Table 1. Distribution of the sample by region and country

\begin{tabular}{l|l|c|c}
\hline Region & Country & No. of plants & \% of total \\
\hline \multirow{2}{*}{ Eastern Europe } & Hungary & 48 & 22.2 \\
\cline { 2 - 4 } & Romania & 35 & 16.2 \\
\hline \multirow{2}{*}{ Asia } & China & 98 & 45.4 \\
\cline { 2 - 4 } & Malaysia & 9 & 4.2 \\
\hline \multirow{2}{*}{ South America } & Brazil & 26 & 12.0 \\
\hline \multicolumn{2}{l|}{ TOTAL } & 216 & 100 \\
\hline
\end{tabular}

Table 2. Distribution of the sample by size and industry

\begin{tabular}{l|c|c}
\hline Employees & Frequency & \% of total \\
\hline Small $(<250)$ & 100 & 46.3 \\
\hline Medium $(250-500)$ & 39 & 18.1 \\
\hline Large $(>500)$ & 77 & 35.6 \\
\hline TOTAL & 216 & 100 \\
\hline
\end{tabular}

\begin{tabular}{l|c|c}
\hline ISIC code & Frequency & \% of total \\
\hline 25 & 69 & 31.9 \\
\hline 26 & 30 & 13.9 \\
\hline 27 & 40 & 18.5 \\
\hline 28 & 42 & 19.4 \\
\hline 29 & 27 & 12.5 \\
\hline 30 & 8 & 3.7 \\
\hline TOTAL & 216 & 100 \\
\hline
\end{tabular}

Notes: ISIC codes: 25: Manufacture of fabricated metal products, except machinery and equipment; 26: Manufacture of computer, electronic and optical products; 27: Manufacture of electrical equipment; 28: Manufacture of machinery and equipment not elsewhere classified; 29: Manufacture of motor vehicles, trailers and semitrailers; 30: Manufacture of other transport equipment. 


\subsection{Variables and measurement model}

Confirmatory factor analysis (CFA) is applied to develop four constructs of internal manufacturing practices, namely quality management (Qual), advanced manufacturing technology (Tech), lean process improvement (LeanProc), and human resource development in manufacturing $(H R)$, and two performance factors, namely cost (CostPerf) and differentiation (DiffPerf).

Table 3. Confirmatory factor analysis results

\begin{tabular}{|c|c|c|c|c|}
\hline Construct & Item & Mean & St. dev. & Path loading \\
\hline \multicolumn{5}{|c|}{ Manufacturing practice constructs } \\
\hline \multirow{3}{*}{ Qual } & Quality improvement and control programs & 3.26 & 1.070 & .750 \\
\hline & Improving equipment availability & 3.28 & 1.077 & .899 \\
\hline & Benchmarking/self-assessment in quality & 3.06 & 1.241 & .812 \\
\hline \multirow{3}{*}{ Tech } & Use of advanced manufacturing processes & 2.69 & 1.212 & .773 \\
\hline & Developing towards the "factory of the future" & 2.45 & 1.132 & .812 \\
\hline & Engaging in process automation programs & 2.75 & 1.174 & .843 \\
\hline \multirow[t]{2}{*}{ LeanProc } & $\begin{array}{l}\text { Restructuring for process focus and streamlin- } \\
\text { ing }\end{array}$ & 3.19 & 1.112 & .741 \\
\hline & Implementing pull production techniques & 3.14 & 1.133 & .758 \\
\hline \multirow{3}{*}{ HR } & Delegation and knowledge improvement & 3.04 & .939 & .736 \\
\hline & Use of autonomous teams & 2.84 & 1.102 & .752 \\
\hline & Improving workers' flexibility & 3.06 & .996 & .678 \\
\hline \multicolumn{5}{|c|}{ Performance improvement constructs } \\
\hline \multirow{3}{*}{ CostPerf } & Unit manufacturing cost & 2.41 & 1.008 & .827 \\
\hline & Order cost & 2.39 & .968 & .782 \\
\hline & Lead time & 2.71 & 1.017 & .692 \\
\hline \multirow{3}{*}{$\begin{array}{l}\text { DiffPerf } \\
\left(2^{\text {nd }}-\text { order }\right. \\
\text { construct })\end{array}$} & QualPerf & 3.43 & .835 & .785 \\
\hline & FlexPerf & 2.75 & .607 & .725 \\
\hline & DelPerf & 3.36 & .782 & .857 \\
\hline \multicolumn{5}{|c|}{ Underlying first-order constructs of DiffPerf } \\
\hline \multirow{2}{*}{ QualPerf } & Conformance quality & 3.22 & .933 & .723 \\
\hline & Product quality and reliability & 3.47 & .919 & .911 \\
\hline \multirow{2}{*}{ FlexPerf } & Volume flexibility & 3.30 & .903 & .832 \\
\hline & Mix flexibility & 3.27 & .864 & .778 \\
\hline \multirow{2}{*}{ DelPerf } & Delivery speed & 3.38 & .938 & .884 \\
\hline & Delivery reliability & 3.42 & .952 & .920 \\
\hline
\end{tabular}

Notes: Path loadings significant at the $\mathrm{p}=.001$ level.

Model fit - absolute fit indices: $\chi^{2}=261.908, \mathrm{p}=.000, \mathrm{df}=152, \chi^{2} / \mathrm{df}=1.723, \mathrm{GFI}=.894$, RMSEA=.058, $\mathrm{SRMR}=.0385$; incremental fit indices: $\mathrm{IFI}=.948, \mathrm{CFI}=.947, \mathrm{TLI}=.934$. 
The four practices were selected on the basis of being the most important bundles of internal practices related to any manufacturing unit's production function, irrespective of the role of the unit within the MNC or in the supply chain. These practices are connected to quality management (Flynn - Saladin 2006; Zu et al. 2010), the use of advanced manufacturing technology (Zhang et al. 2006), lean process development (Shah - Ward 2003) and human resource development (Cagliano et al. 2014; Rogg et al. 2001). In respect of the practice-related questions, respondents had to indicate on a $1-5$ Likert scale $(1=$ None, $5=$ High $)$ the effort put in the last three years into implementing a certain action program. In accordance with the literature, action programs were grouped into broader manufacturing practice bundles (Shah - Ward 2003; Laugen et al. 2005; Voss 2005). For each individual item, several practical examples were provided in the questionnaire in order to facilitate a better and more straightforward understanding.

In respect of the performance questions, respondents had to indicate on a 1-5 Likert scale the extent the plant's manufacturing performance had changed during the last three years. Performance items were grouped in two major performance constructs, cost and differentiation, an approach used in recent empirical studies, for example, by Kawai (2012), or Demeter et al. (2017). The theoretical basis for this approach is offered by Porter's (1985) competitive advantage model, according to which companies can improve their performance either in terms of cost (i.e. efficiency) or differentiation (i.e. quality, flexibility, delivery). For differentiation related items performance change was measured on a conventional Likert-scale (from $1=$ decreased $-5 \%$ or worse, to $5=$ strongly increased $+25 \%$ or better), while for the cost items a reverse scale has been applied (from $1=$ increased $+5 \%$ or worse, to $5=$ strongly decreased $-25 \%$ or more).

CFA results summarized in Table 3 suggest that the measurement model has a good fit to the data. Additionally, the constructs were assessed for convergent and discriminant validity, and construct reliability (Hair et al. 2010), with no serious issues emerging that could undermine the validity and reliability of the proposed measurement model. Convergent validity (i.e. the extent to which items loaded on a construct are related and share a high proportion of variance) was assessed by examining factor loadings, the average variance extracted (AVE) by each construct and construct reliability (CR). All factor loadings are highly significant $(\mathrm{p}<.001)$ and exceed the minimum acceptable value of .50 . Most of the loading exceed the .70 ideal thresholds as well. The AVE values of each construct, computed as the mean variance of the items loaded on the same construct, are above the usual .50 threshold. The CR values all exceed the .70 threshold, indicating a good reliability of each construct. Lastly, discriminant validity was also assessed by comparing the correlation between each pair of constructs with the square root 
of the AVE measure of the two factors. Correlations are clearly lower than AVE square roots, indicating that the main constructs are truly different from each other. Validity and reliability measures are summarized in Table 4.

Table 4. Reliability, convergent and discriminant validity assessment

\begin{tabular}{l|c|c|c|c|c|c|c|c}
\hline & CR & AVE & HR & LeanProc & Tech & Qual & CostPerf & DiffPerf \\
\hline HR & .766 & .522 & .723 & & & & & \\
\hline LeanProc & .719 & .562 & .402 & .750 & & & & \\
\hline Tech & .851 & .656 & .317 & .654 & .810 & & & \\
\hline Qual & .862 & .677 & .605 & .640 & .663 & .823 & & \\
\hline CostPerf & .812 & .591 & .247 & .193 & .288 & .175 & .769 & \\
\hline DiffPerf & .833 & .625 & .422 & .293 & .193 & .255 & .433 & .791 \\
\hline
\end{tabular}

Notes: CR - construct reliability, AVE - average variance extracted, values on the diagonal in italic - square root of AVE, remaining values - pairwise correlations between constructs.

\section{ANALYSIS AND RESULTS}

Before moving on to the investigation of the performance effect of the four manufacturing practice bundles introduced in the previous section, we first explore the implementation efforts related to these practices. Thus, we compare the two subsamples (i.e. local plants and MNC subsidiaries) in terms of the effort undertaken in the last three years to implement the four manufacturing practice bundles. Analysis of variance (ANOVA) is used to discover significant differences between the two subsamples. Results are presented in Table 5.

The results of the ANOVA indicate that, except for advanced manufacturing technology (Tech), MNC subsidiaries invest significantly more effort than local plants into the implementation of manufacturing practices. This finding already suggests that, in general, MNC subsidiaries possess (or at least can access) more knowledge on what practices to implement, and accordingly invest more resources into the implementation.

Next, structural equation modelling (SEM) is used to identify best practices by exploring the relationships between the four practice bundles and the two performance constructs. The measurement model presented in Table 3 is transformed into a structural model with relationships between practice and performance constructs, and is assessed for both subsamples. Results are summarized in Figure 3. For the sake of brevity, only the main constructs are depicted, without the individual items and their error terms loaded on each construct.

SEM results indicate that quality management seems not to be a best practice for the local plants, having no and negative effects, respectively, on the two per- 
Table 5. The use of manufacturing practices in the last three years (ANOVA)

\begin{tabular}{l|c|c|c|c}
\hline \multirow{2}{*}{$\begin{array}{l}\text { Practice } \\
\text { bundle }\end{array}$} & $\begin{array}{c}\text { Local plants } \\
\mathbf{N}=\mathbf{1 4 9}\end{array}$ & $\begin{array}{c}\text { MNC subsidiaries } \\
\mathbf{N}=\mathbf{6 7}\end{array}$ & \multirow{2}{*}{ F-value } & \multirow{2}{*}{ p-value } \\
\cline { 2 - 3 } & Mean (st. dev.) & Mean (st. dev.) & & \\
\hline Qual & $3.19(.905)$ & $3.65(.992)$ & $\mathrm{F}(1,214)=11.203$ & $.001 * * *$ \\
\hline Tech & $2.67(.906)$ & $2.77(.970)$ & $\mathrm{F}(1,214)=.642$ & .424 \\
\hline LeanProc & $2.65(.723)$ & $2.93(.701)$ & $\mathrm{F}(1,214)=7.016$ & $.009 * *$ \\
\hline HR & $2.44(.588)$ & $2.78(.629)$ & $\mathrm{F}(1,214)=14.010$ & $.000 * * *$ \\
\hline
\end{tabular}

Note: The mean difference is significant at the ${ }^{*} \mathrm{p}=.05,{ }^{*} \mathrm{p}=.01,{ }^{* * *} \mathrm{p}=.001$ level.

formance indicators. Advanced manufacturing technology acts as a best practice with a positive significant impact on cost performance. Lean process improvement also takes up a best practice role at local plants, having a positive impact on differentiation performance. Human resource development seems to be a strong best practice with a positive and significant effect on both performance indicators. On the other hand, practice-performance relationships at MNC subsidiaries show both similarities and differences compared to local plants. Quality management is not a best practice at MNC subsidiaries either, with negative effects on cost and differentiation performance. Advanced manufacturing technology, however, seems to be a clear best practice, having positive impact on both performance constructs. Lean process development is not a best practice, while human resource improvement is again a clear best practice, having strong positive impacts on the two performance indicators.

Local plants

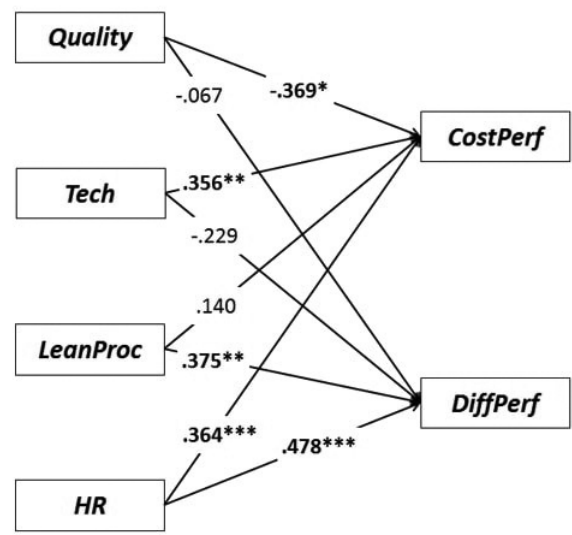

MNC subsidiaries

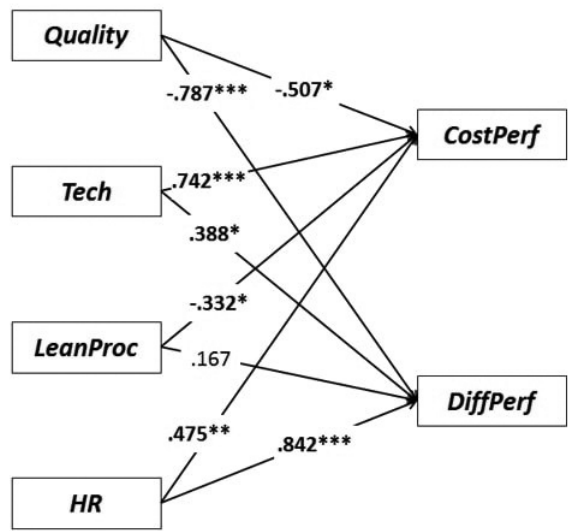

Figure 3. SEM results for the two subsamples

Note: Standardized coefficients are significant at the ${ }^{*} \mathrm{p}=.05, * * \mathrm{p}=.01,{ }^{* * *} \mathrm{p}=.001$ level. 
Nevertheless, to offer a more rigorous answer to our research question, the regression coefficients have to be compared between the two subsamples in order to identify whether the differences are statistically significant between local plants and MNC subsidiaries. For this comparison the unstandardized values of the coefficients have to be used and z-scores are computed to assess the significance of differences. Results are summarized in Table 6.

Table 6. Comparison of practice-performance relationships

\begin{tabular}{l|c|c|c|c|c}
\hline & \multicolumn{2}{|c|}{ Local plants } & \multicolumn{2}{c|}{ MNC subsidiaries } & \multirow{2}{*}{ z-score } \\
\cline { 2 - 5 } & $\begin{array}{c}\text { Unstandardized } \\
\text { (standardized) } \\
\text { coefficient }\end{array}$ & p-value & $\begin{array}{c}\text { Unstandardized } \\
\text { (standardized) } \\
\text { coefficient }\end{array}$ & p-value & \\
\hline Quality -> CostPerf & $-.311(-.369)$ & .013 & $-.385(-.507)$ & .017 & -0.365 \\
\hline Tech -> CostPerf & $.300(.356)$ & .009 & $.577(.742)$ & .000 & 1.580 \\
\hline LeanProc $\rightarrow$ CostPerf & $.148(.140)$ & .302 & $-.357(-.332)$ & .036 & $-2.268^{* *}$ \\
\hline HR -> CostPerf & $.473(.364)$ & .000 & $.569(.475)$ & .004 & 0.411 \\
\hline Quality -> DiffPerf & $-.044(-.067)$ & .615 & $-.469(-.787)$ & .000 & $-2.943^{* * *}$ \\
\hline Tech -> DiffPerf & $-.150(-.229)$ & .063 & $.237(.388)$ & .013 & $3.107^{* * *}$ \\
\hline LeanProc -> DiffPerf & $.307(.375)$ & .002 & $.141(.167)$ & .247 & -1.050 \\
\hline HR -> DiffPerf & $.490(.478)$ & .000 & $.791(.842)$ & .000 & $\mathbf{1 . 7 9 8 *}$ \\
\hline
\end{tabular}

Note: The difference between the two subsamples is significant at the ${ }^{*} \mathrm{p}=.05,{ }^{* *} \mathrm{p}=.01,{ }^{* * *} \mathrm{p}=.001$ level.

Results of the z-test show that while many of the practices have similar performance impacts for both local and MNC plants, some important differences also exist. In terms of the differences two advantages (positive z-scores) and two disadvantages (negative z-scores) for MNC subsidiaries can be identified:

- Advanced manufacturing technology has a positive contribution to differentiation performance at MNC subsidiaries, but it has no effect at local plants. Thus, technology used to improve differentiation seems to be a clear advantage of MNC subsidiaries.

- Human resource development, although with a positive impact on differentiation in both subsamples, has a significantly higher impact on MNC subsidiaries.

- Lean process improvement seems to be less efficient in MNC subsidiaries: it has a negative impact on cost, while at local plants it has no significant impact.

- Quality management, although not being a best practice in either of the two subsamples, has a larger negative impact on differentiation at MNC subsidiaries. 


\section{DISCUSSION AND CONCLUSION}

The main question raised in this paper was whether MNC subsidiaries possess superior manufacturing knowledge compared to domestic firms located in emerging countries, which would ultimately represent a knowledge surplus that creates the possibility for the spillover of valuable knowledge towards domestic firms. More specifically, we aimed to open up the "black box" of MNC subsidiaries and local manufacturing plants operating in five emerging countries to investigate on the plant level the practices they use and the performances they can attain by using these practices. To the best of our knowledge, this is the first study that investigates the possible superior knowledge potential of MNC subsidiaries by directly comparing them to local companies in the emerging countries.

Our results indicate that MNC subsidiaries invest in almost all practices (quality management, lean process improvement, and human resource development) more intensively than local manufacturers. This suggests that on an aggregate level MNC subsidiaries possess more knowledge on manufacturing practices and, as a consequence, invest more effort and resources into their implementation. This result is in line with several previous empirical studies arguing that the main advantage of MNC subsidiaries in the emerging countries is that they can access the knowledge stocks residing within the whole MNC, and are able (or in some cases are imposed) to implement new manufacturing practices (Cheng et al. 2011; Sass - Szalavetz 2013; Linares-Navarro et al. 2014; Demeter - Szász 2016). Despite intensive implementation, two of the four manufacturing practices analyzed are not "best", i.e. are not able to positively contribute to the performance of MNC subsidiaries. First, quality management is not a best practice, neither at MNC subsidiaries, nor at local plants. This is not a surprise, as Laugen et al. (2005) also found that quality management has lost its best practice status by the last decade: it is needed to ensure that basic market requirements are fulfilled, but it is no longer able to offer a competitive edge, i.e. a considerable performance improvement for its implementers. Second, and somewhat surprisingly, lean process improvement has a negative impact on cost at MNC plants, but a positive one on differentiation in case of local plants. Despite intensive investment, MNC subsidiaries are not able to harvest positive performance benefits from lean. This might be a sign of lean maturity, where performance benefits have already been realized at earlier stages of implementation, and are no longer able to significantly contribute to performance (Demeter et al. 2017). Nevertheless, this statement requires further verification.

In terms of the remaining two manufacturing practices, however, we found that MNC subsidiaries have an important knowledge advantage over local plants. Human resource development is clearly a best practice for both types of plants, 
but MNCs are able to realize larger differentiation performance improvements. Advanced manufacturing technology is also clearly different between the two subsamples: while both plant types invest equal amounts in these practices (Table 5), MNC subsidiaries can harvest much higher differentiation performance improvements (Table 6).

In summary, our results indicate that - at least partially - MNC subsidiaries operate differently: they invest more in manufacturing practices, and in two dimensions (advanced manufacturing technology, human resource development) are able to harvest higher performance benefits. Thus, MNCs appear to have some knowledge advantage over local firms in terms of knowledge related to the efficient use of human resource development and advanced manufacturing technology practices.

We have to note that knowledge was measured only indirectly through the use of this knowledge to implement manufacturing practices with the aim of improving performance. Moreover, individual activities were grouped into four practice bundles, making it impossible to investigate manufacturing practice related knowledge on a more fine-grained level. Future research could compare whether the same bundles of practices are used in a similar manner and are composed of the same activities or not at MNC subsidiaries and local companies. This approach could shed more light on why some practices are best at certain companies and could also explain the unexpected findings related to lean process improvement.

Another set of limitations stems from the characteristics of the research sample. While we focused on the emerging countries, we were able to include only a limited set of such countries. Furthermore, the subsample of MNC subsidiaries is rather small. Thus, future research should extend the number of countries and companies and replicate this study in different countries and regions with more representative samples.

The methods used in this paper did not enable us to investigate whether in the manufacturing knowledge domains where $\mathrm{MNC}$ subsidiaries have an advantage over local companies, knowledge actually "leaks" to the actors of the local economy. Further, preferably case study based research should investigate if and how emerging country manufacturing firms (suppliers, customers, competitors) can benefit from cooperating with local MNC subsidiaries by learning from them. 


\section{REFERENCES}

Achcaoucaou, F. - Miravitlles, P. - León-Darder, F. (2014): Knowledge Sharing and Subsidiary R\&D Mandate Development: A Matter of Dual Embeddedness. International Business Review, 23(1): 76-90.

Almeida, P. - Phene, A. (2004): Subsidiaries and Knowledge Creation: The Influence of the MNC and Host Country on Innovation. Strategic Management Journal, 25(8-9): 847-864.

Ambroziak, L. (2018): The CEECS in Global Value Chains. The Role of Germany. Acta Oeconomica, 68(1): 1-29.

Andersson, U. - Björkman, I. - Forsgren, M. (2005): Managing Subsidiary Knowledge Creation: The Effect of Control Mechanisms on Subsidiary Local Embeddedness. International Business Review, 14(5): 521-538.

Andersson, U. - Forsgren, M. - Holm, U. (2002): The Strategic Impact of External Networks: Subsidiary Performance and Competence Development in the Multinational Corporation. Strategic Management Journal, 23(11): 979-996.

Anh, P. T. T. - Baughn, C. C. - Hang, N. T. M. - Neupert, K. E. (2006): Knowledge Acquisition from Foreign Parents in International Joint Ventures: An Empirical Study in Vietnam. International Business Review, 15(5): 463-487.

Bae, S. C. - Noh, S. (2001): Multinational Corporations Versus Domestic Corporations: A Comparative Study of R\&D Investment Activities. Journal of Multinational Financial Management, 11(1): 89-104.

Barbosa, N. - Louri, H. (2005): Corporate Performance: Does Ownership Matter? A Comparison of Foreign- and Domestic-Owned Firms in Greece and Portugal. Review of Industrial Organization, 27(1): 73-102.

Birkinshaw, J. (1996): How Multinational Subsidiary Mandates Are Gained and Lost. Journal of International Business Studies, 27(3): 467-495.

Birkinshaw, J. - Hood, N. - Jonsson, S. (1998): Building Firm-Specific Advantages in Multinational Corporations: The Role of Subsidiary Initiative. Strategic Management Journal, 19(3): 221-242.

Blomström, M. - Kokko, A. (1998): Multinational Corporations and Spillovers. Journal of Economic Surveys, 12(2): 1-31.

Bresciani, S. - Ferraris, A. (2016): Innovation-Receiving Subsidiaries and Dual Embeddedness: Impact on Business Performance. Baltic Journal of Management, 11(1): 108-130.

Cagliano, R. - Caniato, F. - Longoni, A. - Spina, G. (2014): Alternative Uses of Temporary Work and New Forms of Work Organisation. Production Planning \& Control, 25(9): 762-782.

Caves, R. E. (1974): Multinational Firms, Competition, and Productivity in Host-Country Markets. Economica, 41(162): 176-193.

Cheng, Y. - Farooq, S. - Johansen, J. (2011): Manufacturing Network Evolution: A Manufacturing Plant Perspective. International Journal of Operations \& Production Management, 31(12): 1311-1331.

Cohen, W. M. - Levinthal, D. A. (1990): Absorptive Capacity: A New Perspective on Learning and Innovation. Administrative Science Quarterly, 35(1): 128-152.

Da Silveira, G. J. C. - Sousa, R. S. (2010): Paradigms of Choice in Manufacturing Strategy. Exploring Performance Relationships of Fit, Best Practices, and Capability-Based Approaches. International Journal of Operations \& Production Management, 30(12): 1219-1245.

Dachs, B. - Ebersberger, B. - Kinkel, S. - Waser, B. R. (2006): Offshoring of Production - A European Perspective. European Manufacturing Survey, No. 2, Fraunhofer Institute, Karlsruhe. 
Damijan, J. P. - Knell, M. - Majcen, B. - Rojec, M. (2003): The Role of FDI, R\&D Accumulation and Trade in Transferring Technology to Transition Countries: Evidence from Firm Panel Data for Eight Transition Countries. Economic Systems, 27(2): 189-204.

Davies, A. J. - Kochhar, A. K. (2002): Manufacturing Best Practice and Performance Studies: A Critique. International Journal of Operations \& Production Management, 22(3): 289-305.

Demeter, K. - Matyusz, Z. (2011): The Impact of Lean Practices on Inventory Turnover. International Journal of Production Economics, 133(1): 154-163.

Demeter, K. - Szász, L. (2016): The Diversity of European Manufacturing Plant Roles in International Manufacturing Networks. Journal of East European Management Studies, 21(2): 184208.

Demeter, K. - Szász, L. - Boer, H. (2017): Plant Role and the Effectiveness of Manufacturing Practices. International Journal of Operations \& Production Management, 37(12): 1773-1794.

Demeter, K. - Szász, L. - Rácz, B. G. (2016): The Impact of Subsidiaries' Internal and External Integration on Operational Performance. International Journal of Production Economics, 182: $73-85$.

Dunning, J. H. (1998): Location and the Multinational Enterprise: A Neglected Factor? Journal of International Business Studies, 29(1): 45-66.

Easterby-Smith, M. - Lyles, M. A. - Tsang, E. W. K. (2008): Inter-Organizational Knowledge Transfer: Current Themes and Future Prospects. Journal of Management Studies, 45(4): 677690.

Feldmann, A. - Olhager, J. (2013): Plant Roles: Site Competence Bundles and Their Relationships with Site Location Factors and Performance. International Journal of Operations \& Production Management, 33(6): 722-744.

Ferdows, K. (1997): Making the Most of Foreign Factories. Harvard Business Review, 75: 73-91.

Ferdows, K. (2006): Transfer of Changing Production Know-How. Production and Operations Management, 15(1): 1-9.

Ferraris, A. - Santoro, G. - Bresciani, S. (2017): Open Innovation in Multinational Companies' Subsidiaries: The Role of Internal and External Knowledge. European Journal of International Management, 11(4): 452-468.

Figueiredo, P. N. (2011): The Role of Dual Embeddedness in the Innovative Performance of MNE Subsidiaries: Evidence from Brazil. Journal of Management Studies, 48(2): 417-440.

Firth, R. - Ghauri, P. N. (2010): Multinational Enterprise Acquisitions in Emerging Markets: Linkage Effects on Local Firms. European Journal of International Management, 4(1-2): 135-162.

Flynn, B. B. - Saladin, B. (2006): Relevance of Baldrige Constructs in an International Context: A Study of National Culture. Journal of Operations Management, 24(5): 583-603.

Frost, T. S. - Birkinshaw, J. M. - Ensign, P. C. (2002): Centers of Excellence in Multinational Corporations. Strategic Management Journal, 23(11): 997-1018.

Fusco, J. P. - Spring, M. (2003): Flexibility versus Robust Networks: The Case of the Brazilian Automotive Sector. Integrated Manufacturing Systems, 14(1): 26-35.

Golini, R. - Deflorin, P. - Scherrer, M. (2016): Exploiting the Potential of Manufacturing Network Embeddedness: An OM Perspective. International Journal of Operations \& Production Management, 36(12): 1741-1768.

Greene, W. H. - Hornstein, A. S. - White, L. J. (2009): Multinationals Do It Better: Evidence on the Efficiency of Corporations' Capital Budgeting. Journal of Empirical Finance, 16(5): 703-720.

Gupta, A. K. - Govindarajan, V. (2000): Knowledge Flows within Multinational Corporations. Strategic Management Journal, 21(4): 473-496.

Hansen, M. W. - Pedersen, T. - Petersen, B. (2009): MNC Strategies and Linkage Effects in Developing Countries. Journal of World Business, 44(2): 121-130. 
Javorcik, B. S. (2004): Does Foreign Direct Investment Increase the Productivity of Domestic Firms? In Search of Spillovers through Backward Linkages. The American Economic Review, 94(3): 605-627.

Jensen, P. D. O. - Pedersen, T. (2011): The Economic Geography of Offshoring: The Fit between Activities and Local Context. Journal of Management Studies, 48(2): 352-372.

Kawai, N. (2012): The Influence of External Network Ties on Organisational Performance: Evidence from Japanese Manufacturing Subsidiaries in Europe. European Journal of International Management, 6(2): 221-242.

Ketokivi, M. - Ali-Yrkkö, J. (2009): Unbundling R\&D and Manufacturing: Postindustrial Myth or Economic Reality? Review of Policy Research, 26(1-2): 35-54.

Kinkel, S. (2012): Trends in Production Relocation and Backshoring Activities. Changing Patterns in the Course of the Global Economic Crisis. International Journal of Operations \& Production Management, 32(6): 696-720.

Kinoshita, Y. (2001): R\&D and Technology Spillovers via FDI: Innovation and Absorptive Capacity. Working Paper, No. 349a.

Kogut, B. - Zander, U. (1992): Knowledge of the Firm, Combinative Capabilities, and the Replication of Technology. Organization Science, 3(3): 383-397.

Kogut, B. - Zander, U. (1993): Knowledge of the Firm and the Evolutionary Theory of the Multinational Corporation. Journal of International Business Studies, 24(4): 625-645.

Kostova, T. (1999): Transnational Transfer of Strategic Organizational Practices: A Contextual Perspective. Academy of Management Review, 24(2): 308-324.

Lane, P. J. - Koka, B. R. - Pathak, S. (2006): The Reification of Absorptive Capacity: A Critical Review and Rejuvenation of the Construct. Academy of Management Review, 31(4): 833-863.

Lane, P. J. - Salk, J. E. - Lyles, M. A. (2001): Absorptive Capacity, Learning, and Performance in International Joint Ventures. Strategic Management Journal, 22(12): 1139-1161.

Laugen, B. T. - Acur, N. - Boer, H. - Frick, J. (2005): Best Manufacturing Practices: What do the Best-Performing Companies Do? International Journal of Operations \& Production Management, 25(2): 131-150.

Lavie, D. - Fiegenbaum, A. (2003): The Dominant Strategic Positioning of Foreign MNCS: A Typological Approach and the Experience of Israeli Industries. Journal of Business Research, 56(10): 805-814.

Linares-Navarro, E. - Pedersen, T. - Pla-Barber, J. (2014): Fine Slicing of the Value Chain and Offshoring of Essential Activities: Empirical Evidence from European Multinationals. Journal of Business Economics and Management, 15(1): 111-134.

London, T. - Hart, S. L. (2004): Reinventing Strategies for Emerging Markets: Beyond the Transnational Model. Journal of International Business Studies, 35(5): 350-370.

Marin, A. - Bell, M. (2006). Technology Spillovers from Foreign Direct Investment (FDI): The Active Role of MNC Subsidiaries in Argentina in the 1990s. The Journal of Development Studies, 42(4): 678-697.

Mariotti, S. - Mutinelli, M. - Nicolini, M. - Piscitello, L. (2015): Productivity Spillovers from Foreign Multinational Enterprises to Domestic Manufacturing Firms: To What Extent does Spatial Proximity Matter? Regional Studies, 49(10): 1639-1653.

Meyer, K. E. - Mudambi, R. - Narula, R. (2011): Multinational Enterprises and Local Contexts: The Opportunities and Challenges of Multiple Embeddedness. Journal of Management Studies, 48(2): 235-252.

Michel, A. - Shaked, I. (1986): Multinational Corporations vs. Domestic Corporations: Financial Performance and Characteristics. Journal of International Business Studies, 17(3): 89-100. 
Mills. J. - Platts, K. - Gregory, M. (1995): A Framework for the Design of Manufacturing Strategy Processes: A Contingency Approach. International Journal of Operations \& Production Management, 15(1): 17-49.

Minbaeva, D. (2007): Knowledge Transfer in Multinational Corporations. Management International Review, 47(4): 567-593.

Mudambi, R. (2008): Location, Control and Innovation in Knowledge-Intensive Industries. Journal of Economic Geography, 8(5): 699-725.

Mudambi, R. - Pedersen, T. - Andersson, U. (2014): How Subsidiaries Gain Power in Multinational Corporations. Journal of World Business, 49(1): 101-113.

O'Dell, C. - Grayson, C. J. (1998): If Only We Knew What We Know: Identification and Transfer of Internal Best Practices. California Management Review, 40(3): 154-174.

Perrin, A. - Rolland, N. - Stanley, T. (2007): Achieving Best Practices Transfer across Countries. Journal of Knowledge Management, 11(3): 156-166.

Porter, M. E. (1985), Competitive Advantage: Creating and Sustaining Superior Performance, New York: The Free Press.

Rogg, K. L. - Schmidt, D. B. - Shull, C. - Schmitt, N. (2001): Human Resource Practices, Organizational Climate, and Customer Satisfaction. Journal of Management, 27(4): 431-449.

Rugman, A. - Verbeke, A. - Yuan, W. (2011): Re-Conceptualizing Bartlett and Ghoshal's Classification of National Subsidiary Roles in the Multinational Enterprise. Journal of Management Studies, 48(2): 253-277.

Sass, M. - Szalavetz, A. (2013): Crisis and Upgrading: The Case of the Hungarian Automotive and Electronics Sectors. Europe-Asia Studies, 65(3): 489-507.

Shah, R. - Ward, P.T. (2003): Lean Manufacturing: Context, Practice Bundles, and Performance. Journal of Operations Management, 21(2): 129-149.

Sila, I. (2007): Examining the Effects of Contextual Factors on TQM and Performance through the Lens of Organizational Theories: An Empirical Study. Journal of Operations Management, 25(1): 83-109.

Sousa, R. - Voss, C. (2001): Quality Management: Universal or Context Dependent? Production and Operations Management, 10(4): 383-404.

Sousa, R. - Voss, C. A. (2008): Contingency Research in Operations Management Practices. Journal of Operations Management, 26(6): 697-713.

Sveiby, K. E. (2001): A Knowledge-Based Theory of the Firm to Guide in Strategy Formulation. Journal of Intellectual Capital, 2(4): 344-358.

Szász, L. - Demeter, K. (2015): Business Models Along Supply Chain Position and Servitisation: An Empirical Investigation of European Manufacturers. Acta Oeconomica, 65(3): 367-391.

Szász, L. - Rácz, B. G. - Scherrer, M. - Deflorin, P. (2019): Disseminative Capabilities and Manufacturing Plant Roles in the Knowledge Network of MNCs. International Journal of Production Economics, 208: 294-304.

Szász, L. - Scherrer-Rathje, M. - Deflorin, P. (2016): Benefits of Internal Manufacturing Network Integration: The Moderating Effect of Country Context. International Journal of Operations \& Production Management, 36(7): 757-780.

Szulanski, G. (1996): Exploring Internal Stickiness: Impediments to the Transfer of Best Practice within the Firm. Strategic Management Journal, 17: 27-43.

Tsai, W. (2001): Knowledge Transfer in Intraorganizational Networks: Effects of Network Position and Absorptive Capacity on Business Unit Innovation and Performance. Academy of Management Journal, 44(5): 996-1004. 
Van Wijk, R. - Jansen, J. J. P. - Lyles, M. A. (2008): Inter- and Intra-Organizational Knowledge Transfer: A Meta-Analytic Review and Assessment of its Antecedents and Consequences. Journal of Management Studies, 45(4): 830-853.

Voss, C. A. (1995): Alternative Paradigms for Manufacturing Strategy. International Journal of Operations \& Production Management, 15(4): 5-16.

Voss, C. A. (2005): Paradigms of Manufacturing Strategy Re-Visited. International Journal of Operations \& Production Management, 25(12): 1223-1227.

Wei, Y. - Liu, X. (2006): Productivity Spillovers from R\&D, Exports and FDI in China's Manufacturing Sector. Journal of International Business Studies, 37(4): 544-557.

Yang, Q. - Mudambi, R. - Meyer, K. E. (2008): Conventional and Reverse Knowledge Flows in Multinational Corporations. Journal of Management, 34(5): 882-902.

Zhang, Q. - Vonderembse, M. A. - Cao, M. (2006): Achieving Flexible Manufacturing Competence: The Roles of Advanced Manufacturing Technology and Operations Improvement Practices. International Journal of Operations \& Production Management, 26(6): 580-599.

Zu, X. - Robbins, T. L. - Fredendall, L. D. (2010): Mapping the Critical Links between Organizational Culture and TQM/Six Sigma Practices. International Journal of Production Economics, 123(1): 86-106. 